\title{
English vis-à-vis Italian Aspectual Verb Constructions: The Case of Continuative Aspectualizers
}

\author{
Daniele Franceschi ${ }^{1}$ \\ ${ }^{1}$ Department of Foreign Languages, Literatures and Cultures, Roma Tre University, Rome, Italy \\ Correspondence: Daniele Franceschi, Department of Foreign Languages, Literatures and Cultures, Roma Tre \\ University, Via Ostiense 234-236, 00146 Rome, Italy. E-mail: daniele.franceschi@uniroma3.it
}

Received: July 20, 2020

Accepted: August 25, $2020 \quad$ Online Published: August 30, 2020

doi:10.5539/ijel.v10n5p39

URL: https://doi.org/10.5539/ijel.v10n5p39

\begin{abstract}
This paper provides an initial analysis of continuative aspectualizers from a contrastive English-Italian perspective. The aim is to investigate the areas of overlap and contrast in terms of the lexico-syntactic behaviour and semantic scope of the main continuative verbs in the two languages, i.e., keep, continue, proceed, resume vs. (man)tenere, continuare, procedere, riprendere. The focus will also be on the identification of the cognitive factors that interact with the prototypical features of these predicates, licensing or blocking the constructions types that can embed them. Two primary mapping operations, namely metonymy and metaphor, will be observed to motivate the behaviour of continuative aspectualizers in transitive and intransitive constructions as well as in less common patterns, such as the middle, reflexive and resultative construction.
\end{abstract}

Keywords: continuative aspectualizers, English, Italian, cognitive operations

\section{Introduction}

Aspectual verb constructions are morphosyntactic configurations characterized by different degrees of complexity and with specific grammatical, lexico-semantic and pragmatic features that vary cross-linguistically. They are high-frequency patterns embedding predicates indicating the state of progression of an event, i.e., its inception (start, begin, commence, initiate), continuation (continue, keep, resume, proceed) or conclusion (stop, end, finish, terminate), and producing several structural realizations and meanings depending on the context of their use.

Previous studies have predominantly focused on the analysis of aspectual verbs in terms of their most common projections onto syntax, such as the to-infinitive and the -ing form in English (cf., among others, Brinton, 1988; Wierzbicka, 1988; Bailey, 1993; Duffley, 1999, 2006; Fukuda, 2007; Mair, 2009), and on their core semantics (Freed, 1979; Tobin, 1993), disregarding, on the one hand, the fact that aspectual verbs appear in different types of more or less prototypical constructions and, on the other hand, that they often produce less core meanings resulting from the "manipulation" of their internal semantics through a process of coercion (Michaelis, 2003). Consequently, the interpretation of specific aspectual verb constructions is possible due to a range of figurative meaning extensions, typically involving cognitive operations such as metonymy and metaphor.

The present paper provides a cross-linguistic investigation of one subclass of aspectual verbs, i.e., continuative aspectualizers, in English and Italian. The focus is on the areas of overlap and contrast between the two languages, with the aim of broadening the theoretical understanding of how they work with respect to this verb class. Four main continuative aspectualizers are examined contrastively, namely keep/(man)tenere, continue/continuare, proceed/procedere and resume/riprendere, both by relying on OPUS (Note 1), a parallel corpus of translated texts from the web that was queried with Sketch Engine (Note 2), and on authentic occurrences retrieved in Google Books. Section 2 analyzes the syntactic behaviour of these predicates and highlights the similarities, but, above all, the differences between the types of constructions that they can participate in. It will be observed that in addition to appearing in what can be considered as prototypical configurations, i.e., the to-infinitive and the gerund form in English (Celeste continued to speak to him while [...]; Everyone keeps talking about holidays) and the 'continuare $a+$ infinitive' construction in Italian (Continua sempre a scriverti?), continuative aspectualizers can also be subsumed under less common patterns, such as the middle, the resultative and the reflexive construction. Section 3 examines the semantic features of continuative aspectualizers in order to show, among other things, how etymologically related words have evolved differently in the two languages; translation is used as a powerful heuristic tool in the investigation of inter-linguistic variability in that it brings to the fore the mismatches at 
different levels of analysis. Section 4 illustrates the cognitive operations underlying and motivating the various realizations of continuative verb constructions in English and Italian. It will be shown that the differences between the two languages often reside in the way in which they conceptualize the events that they reify. Section 5 reflects on and summarizes the main points covered throughout the paper.

\section{Lexico-Syntactic Configurations}

The prototypical continuative verb construction in English consists of the continuative verb itself followed by the gerund form. Although not only continuative verbs but also the other aspectual predicates control post-predicate -ing clauses (e.g., [...] he began writing the novel at the start of 1793 [...] (Note 3); The baby stopped crying (Note 4), the inherent progressive meaning of the former makes them particularly prone to combine with the gerund, which also indicates that a certain activity is in progress. All the four English continuative verbs examined allow for the use of the -ing clause, but keep seems to be the most common predicate controlling this type of complement clause. According to Biber et al. (1999, p. 741), keep occurs over 70 times per million words with the -ing clause, which makes it the most frequent aspectual verb of all appearing in this syntactic pattern (e.g., You are the one who keeps talking about what I want) (Note 5). It can be argued then that the -ing clause is the hallmark of aspectual verbs in general and of keep in particular. On the other hand, keep does not control the to-infinitive clause (*You are the one who keeps to talk about...), which is instead a very frequent structure associated with the other aspectual verbs. The fact that English allows for the use of continuative verbs both with the gerund form and the to-infinitive (with the only exception of keep) makes it syntactically less restricted than Italian, which always requires an infinitive complement clause introduced by the preposition $a$. The following examples taken from OPUS show the lower level of syntactic variability in Italian with respect to verbal complement clauses:

(1) He keeps going outside and coming back again > Continua a uscire e a tornare dentro.

(2) That is the road the presidency intends to continue going down > Questa è la strada che la Presidenza intende continuare a seguire.

(3) This baseline scenario for growth continues to be surrounded by a good deal of uncertainty > Questo scenario di base per la crescita continua a essere caratterizzato da un notevole grado di incertezza.

(4) a. Last February, the management of the Bawo company proceeded to remove the machinery from its factory [...].

b. Le monete non adatte alla circolazione e ritirate dovranno essere consegnate in un imballaggio specifico e gli Stati membri procederanno a distruggerle.

[Coins not suitable for circulation and withdrawn will have to be delivered in a specific packaging and Member States will proceed to destroy them].

(5) As soon as he got well, he resumed working. > Non appena si rimise, riprese a lavorare.

Since OPUS is a relatively small corpus, there are almost no occurrences of less frequent constructions, which however appear in larger datasets, such as Google Books. The verb proceed, for instance, is seldom followed by the -ing form in OPUS, but this pattern is well-represented in Google Books (6); in Italian, it naturally translates as procedere followed, once again, by the preposition $a$ and the infinitive construction. (Note 6 ). The latter is a more natural syntactic configuration also appearing in OPUS, as can be observed in (4b) above:

(6) The doctor nodded to Phil and me, then proceeded talking directly to Rie. (Note 7)

Similarly, in OPUS there are no occurrences of resume in combination with the to-infinitive, which, albeit less common, can be retrieved in Google Books too (7):

(7) Arthur turned to page 10 and resumed to read aloud to her. (Note 8)

On the other hand, riprendere $a+$ infinitive is a natural syntactic construction and frequently appears in OPUS:

(8) Le quotazioni hanno ripreso a salire nella seconda metà di gennaio [...].

[Prices started to rise again in the second half of January...].

The behaviour of the continuative aspectualizers under investigation here does not change cross-linguistically with respect to transitivity or intransitivity. There appear to be complete syntactic overlaps among the four English verbs and the four Italian ones, i.e., they all enter the intransitive construction and only two of them, namely proceed and procedere, cannot be used transitively.

The middle construction, in which the subject plays the semantic role of theme or patient, also allows interchangeability among the verbs both in English and Italian, but the backgrounding of agentivity in association 
with keep is likely to be translated with the 'si passivante' construction in Italian (9):

(9) a. Your homemade convenience breakfast foods will keep well in the freezer. (Note 9)

b. Il brodo di carne o di pesce si mantiene bene in frigo per almeno 7 giorni [...]. (Note 10)

[Meat or fish broth keeps well in the fridge for at least 7 days...].

There are instead restrictions in the use of the resultative construction. The two verbs that are typically subsumed under it are keep and (man)tenere (10-11). Italian appears as more flexible than English in that it also allows continuare and procedere in non-causative resultative constructions, but the two verbs seem to take on a copular function (12):

(10) a. I keep my hair short. (Note 11)

b. Per un po' tengo io capelli corti come mi piace [...]. (Note 12)

(11) a. [...] he cannot keep the ship at sea [...]. (Note 13)

b. [...] mantenere la nave stabile [...]. (Note 14)

(12) a. La vita sul Pianoro continuò felice per molto tempo [...]. (Note 15)

[Life in the Pianoro continued happy for a long time...].

b. Gina procede felice con il suo fidanzato [...]. (Note 16)

[Gina proceeds happy with her boyfriend...].

It may be argued that felice (happy) in 12a is both a condition resulting from the continuation of a certain state of affairs and an already existing property of the subject. In the latter case, the continuative aspectualizer could be substituted with the copular verb to be (La vita sul Pianoro fu felice per molto tempo > 'Life in the Pianoro was happy for a long time) without substantially changing the meaning of the sentence. In $12 \mathrm{~b}$, is the subject 'happy' in the first place or because she is proceeding with her boyfriend? These are two examples showing us that the dividing line between one construction type and the other is sometimes not so clear-cut.

The reflexive construction naturally embeds continuative aspectualizers in English, while in Italian they are nearly always ruled out except in specific contexts. Unlike (man)tenere, which also has a reflexive form, i.e., (man)tenersi (13), the other Italian continuative aspectualizers do not combine felicitously with reflexive pronouns. On the other hand, continue, proceed and resume may be followed by them (14):

(13) Mantenersi in buona salute. (Note 17)

[Keep oneself in good health].

(14) a. [...] an impulsion which continues itself in a direction the inverse of materiality. (Note 18)

b. There is good reason to think that the way in which research in physics proceeds itself canalizes and limits the interpretation that [...]. (Note 19)

c. [...] a moment that would linger before the conversation resumed itself. (Note 20)

Reflexive pronouns can obviously be omitted here without altering the core meaning of the sentence. Their function is simply that of emphasizing and highlighting the action referred to rather than the person performing it. While this use appears in general English, Italian seems to allow the insertion of a reflexive pronoun with the same subject-highlighting function in technical-scientific contexts (15):

(15) L'aorta si continua con l'arteria iliaca. (Note 21)

[The aorta continues itself in the iliac artery].

In addition to the similarities and differences in the syntactic behaviour of continuative aspectualizers in the main construction types, each verb in the two languages also has its own specific, idiosyncratic properties. In English, for instance, keep and resume participate in the ' $\mathrm{X}$ asp-v $\mathrm{Y}$ v-ing' construction (16), which is incompatible with continue and proceed, and non-existent in Italian:

(16) a. Perpetual spending keeps the music playing. (Note 22)

b. I resumed the music playing on my phone. (Note 23)

The corresponding construction in Italian consists of a more complex structure involving the expression far (e) si che (which roughly translates as 'make'), often followed by the subjunctive mode (17a), or the fare + infinitive pattern with the meaning of 'make something happen' (17b): 
(17) a. La spesa perpetua fa sì che la musica continui. (Note 24)

[Perpetual spending makes the music continue playing].

b. Ho fatto ripartire la musica sul telefono. (Note 25)

[I made the music restart playing on my phone].

In this particular case, Italian seems to require a lower degree of specification than English. While the verb in the gerund form following the $\mathrm{Y}$ element in the ' $\mathrm{X}$ asp-v $\mathrm{Y}$ v-ing' construction cannot be omitted, the action it refers to (i.e., playing) may remain implicit in Italian and the meaning will then be derived contextually.

The type of argument also appears to constrain the syntactic realizations of continuative aspectualizers. We have seen above, for instance, that the verb keep may be associated to a human-agentive subject (He keeps going outside and coming back again) as well as to a non-human, non-agentive subject (Your homemade convenience breakfast foods will keep well in the freezer). In the English resultative construction, the alternation between subjects with different semantic roles does not seem to have repercussions at the structural level (18), while in Italian the object undergoing the process of change may be omitted if the subject is an inanimate entity; what we obtain in this case though is no longer a resultative construction (19a), but a middle construction, instead (19b):

(18) a. [...] I keep my hair short all over. (Note 26)

b. A woollen sweater keeps you warm on a cold day. (Note 27)

(19) a. Adesso ti do una cosa che ti tiene caldo. Ecco, metti questo. (Note 28)

[I will now give you something that will keep you warm. Here. Put it on].

b. È un maglione che tiene molto caldo. (Note 29)

[This is a sweater that will keep you warm].

This possibility is ruled out in English in that the omission of the object would produce an incorrect sentence (20):

(20) *A woollen sweater keeps warm on a cold day.

Both the verb resume and riprendere enter the transitive construction, but the former requires an object which at least implicitly refers to an activity (21), while in Italian this is not a necessary condition (22). Since both verbs can be used transitively, it is obviously the semantic nature of the object that imposes restrictions:

(21) a. [...] she resumed her job on the switchboard at the front desk. (Note 30)

b. *She resumed the baby in her arms.

(22) a. Samanta ha ripreso il lavoro con la terapeuta che l'aveva seguita in precedenza. (Note 31)

[Samanta resumed her therapy with the psychologist who...].

b. Archy riprese in braccio il bambino. (Note 32)

[Archy took the boy in his arms again/Archy picked up the boy again].

A thorough analysis would certainly require a finer-grained investigation of the various other semantic features of the arguments of continuative aspectualizers that affect their structural representation. Due to space limits, however, it has only been possible to provide a preliminary examination of the main syntactic differences in the two languages.

\section{Semantic Relations}

The most prominent aspect emerging when comparing the semantic profiles of pairs of continuative aspectualizers is that strict cross-linguistic equivalence is not possible due to differences in the scope of their field of reference. This is a well-known phenomenon that does not just involve words belonging to this verb class. Lack of equivalence at various levels of linguistic analysis is common (García, Florimon van Putte, \& Yishai, 1987; Tognini Bonelli, 2002; Bertuccelli Papi, 2016). It is very unlikely for words in general, even when they share the same etymology, to encapsulate the exact same meaning across languages, owing both to diachronic evolution and to language-specific variations. Therefore, although a lexeme in one language is often typically translated with a certain other lexeme in another language, the two items will most probably vary at some level of their semantic makeup.

\subsection{Related Senses in MultiWordNet}

The use of MultiWordNet (Note 33), a multilingual lexical database in which words are grouped into sets of cognitive synonyms, makes it possible to identify the main idiosyncrasies of continuative aspectualizers in English 
and Italian, such as lexical gaps and denotational differences. In order to analyze data contrastively, the search in MultiWordNet has to be performed starting with an Italian item, which the system will then automatically compare with the corresponding English one(s). Table 1 summarizes the Italian and English senses associated to the continuative aspectualizers examined in the paper (Note 34).

Table 1. Lexical-semantic profiles of continuative aspectualizers in MultiWordNet

\begin{tabular}{|c|c|c|}
\hline Italian synsets & English synsets & English glosses \\
\hline \multirow[t]{2}{*}{ tenere } & TAKE_UP & 1. Take up time or space: "take up the slack" \\
\hline & KEEP & 2. Look after; be the keeper of; have charge of: "He keeps the bees on the estate" \\
\hline $\begin{array}{l}\text { mantenere, } \\
\text { tenere, avere, } \\
\text { conservare }\end{array}$ & KEEP, MAINTAIN, HOLD & $\begin{array}{l}\text { 1. Keep in a certain state, position, or activity: "keep clean"; "hold in place"; "she } \\
\text { always held herself as a lady" }\end{array}$ \\
\hline $\begin{array}{l}\text { mantenere, } \\
\text { tenere }\end{array}$ & KEEP, HOLD_ON & 2. Retain possession of \\
\hline $\begin{array}{l}\text { continuare, } \\
\text { proseguire, } \\
\text { seguitare }\end{array}$ & $\begin{array}{l}\text { CONTINUE, GO_ON, PROCEED, } \\
\text { GO_ALONG, KEEP_ON, KEEP }\end{array}$ & $\begin{array}{l}\text { 1. Continue a certain state, condition, or activity: "Keep on working!"; "We } \\
\text { continued to work into the night"; "Keep smiling"; "We went on working until well } \\
\text { past midnight". }\end{array}$ \\
\hline $\begin{array}{l}\text { continuare, } \\
\text { procedere, } \\
\text { proseguire, } \\
\text { seguitare, andare } \\
\text { avanti }\end{array}$ & $\begin{array}{l}\text { CONTINUE, GO_ON, } \\
\text { CARRY_ON, PROCEED }\end{array}$ & 2. Continue to speak: "I know it's hard," he continued "but there is no choice." \\
\hline \multirow[t]{3}{*}{ riprendere } & RESUME & 1. Assume anew: "resume a title"; "resume an office"; "resume one's duties" \\
\hline & RESUME, RESTART & 2. Take up or begin anew: "We resumed the negotiations" \\
\hline & RESUME, TAKE_UP & $\begin{array}{l}\text { 3. Return to a previous location or condition: "The painting resumed its old } \\
\text { condition when we restored it" }\end{array}$ \\
\hline $\begin{array}{l}\text { proseguire, } \\
\text { seguire }\end{array}$ & CONTINUE & $\begin{array}{l}\text { Continue after an interruption: "The demonstration continued after a break for } \\
\text { lunch" }\end{array}$ \\
\hline
\end{tabular}

We can observe that keep is semantically related to (man)tenere, even if the synsets of the two verbs do not completely coincide. Unfortunately, MultiWordNet only seldom provides examples in Italian and here we do not have anything with which we can compare the English sentences provided along with the glosses. Incidentally, some example sentences are also missing in English, as in the case of the 'regain possession of' sense of keep and hold on. However, mantenere seems to be related to conservare (preserve) and avere (have), two senses that do not appear to be synonyms of keep. In addition, the 'take up' sense of tenere is exemplified with a sentence (Take up the slack) that could be translated with a fixed phrase in Italian, e.g., datti/datevi da fare. This expression does not entail the meaning of tenere or take up. Take up time and take up space are best rendered in Italian as prendere tempo and occupare spazio, respectively. Therefore, the correspondence between tenere and take up is ambiguous, but it makes sense to say that keep and tenere are similar as regards the 'look after/be the keeper of/have charge of' sense. As a matter of fact, the example He keeps the bees on the estate can be felicitously translated as Tiene le api nella tenuta (Note 35).

Continue and continuare share most of their senses and they both overlap with the semantics of proceed/procedere. The first group of English synsets of continue also includes keep and the prepositional verb keep on. Italian tends to have fewer colloquial alternatives to continuare than English, which in addition to Latin-based words also uses go on and carry on as continuative aspectualizers. Interestingly, continue is embedded in the semantics of proceed, but only seguire appears to be a synonym of proseguire.

Finally, resume and riprendere have semantic features in common, but MultiWordNet only provides restart and take up as possible readings of resume. However, this also works with riprendere, which can be replaced by riniziare in sentences such as Riniziammo i negoziati. Both resume and riprendere thus entail an ingressive meaning component.

\subsection{Semiotic Relations}

Keep appears as the most diagrammatic of the four English verbs examined here (Note 36). Because it points to 
various meanings, it is the least transparent on a parameter of indexicality (Note 37). Its complexity emerges clearly during the process of translation. The fact that it can be variously rendered in Italian is proof of its broad semantic range. Its continuative meaning lends itself well to being "manipulated" to obtain different interpretations, as can be seen in Table 2 below, which shows the most frequent Italian translations of the verb in OPUS.

Table 2. Raw and percentage frequency of Italian translations of keep in OPUS

\begin{tabular}{lll}
\hline Frequency & Raw frequency & Percentage frequency \\
\hline tenere & 17,702 & $33.24 \%$ \\
continuare & 5,637 & $10.58 \%$ \\
mantenere & 4,307 & $8.08 \%$ \\
conservare & 2,566 & $4.81 \%$ \\
stare & 101 & $0.18 \%$ \\
rimanere & 19 & $0.03 \%$ \\
seguire & 12 & $0.02 \%$ \\
other & 22,898 & $43 \%$ \\
\hline
\end{tabular}

Although tenere appears as the most common counterpart of keep, other translations are possible too; the most striking aspect is perhaps that there can be many ways of "cutting up" the conceptual space of keep that in Italian do not necessarily involve the use of a continuative aspectualizer. All these cases are grouped under 'other'. Example 23 shows, for instance, that a possible reading of keep is also that of 'preserving', which is conceptually more elaborate than simply 'maintaining' (Note 38). Keep entails a more basic sense of 'making' in this context, as can also be seen in example 24:

(23) Keeping inflation expectations firmly anchored in line with our objective and securing price stability in the medium term will support sustainable growth and employment and contribute to financial stability $>$ Preservare il saldo ancoraggio delle aspettative di inflazione in linea con il nostro obiettivo...

(24) It's always the woman who keeps things going > È sempre la donna che fa funzionare le cose.

In translation, we inevitably foreground or background portions of word meaning. This is a necessary process because full cross-linguistic equivalence is not achievable and some form of lexical-semantic adaptation is always required (Bassnett \& Bush 2006; Raw 2012). Back-translation will then allow us to measure the degree of deviation between the source and the target item. Because back-translation of (24) can be easily obtained, we can confirm that keep can be substituted with make in that the semantics of the two verbs overlap to a certain extent:

(25) È sempre la donna che fa funzionare le cose > It's always the woman who makes things work.

The core semantics of continue is not subject to as many meaning extensions as in the case of keep, i.e., it remains more closely related to its original Latin sense of 'being uninterrupted/continuous' (continere or continuare). Therefore, it is transparent on a parameter of indexicality. In other words, it tends to be more biunique than keep, because it unambiguously refers to the concept of 'going on' both from a spatial and temporal point of view. This basic meaning component is analogous to that of Italian continuare. Such correspondence explains why continuare is the most frequent translation of continue in OPUS (Table 3). Depending on the context of use, however, continue may also be translated as 'resume' and 'proceed, which presuppose continuation after an interruption and a succession of physical movements or series of actions to be performed, respectively.

Table 3. Raw and percentage frequency of Italian translations of continue in OPUS

\begin{tabular}{lll}
\hline Frequency & Raw frequency & Percentage frequency \\
\hline continuare & 14,958 & $50.46 \%$ \\
proseguire & 2,359 & $7.95 \%$ \\
riprendere & 200 & $0.67 \%$ \\
seguitare & 78 & $0.26 \%$ \\
permanere & 33 & $0.11 \%$ \\
\hline
\end{tabular}

As far as seguitare and permanere are concerned, the low frequency of occurrence of the former may be due to its rather old-fashioned nature, while the latter expresses a more specific meaning (Note 39) and is thus less represented. 
Proceed and resume are also less frequent than the other continuative aspectualizers in English, because their semantic scope is narrower. Unlike the other verbs, proceed is non-implicative, i.e., it does not necessarily presuppose the successful realization of the complement event it introduces. Therefore, it may take on the meaning of 'approaching' if what follows is negated, e.g., he proceeded to drink, but then he didn't drink. This sense is not produced in the presence of an -ing form, which works as a presupposition trigger. In other words, he proceeded drinking implies that the drinking took place, but he proceeded to drink does not. In OPUS, proceed is variously translated (Table 4); there does not seem to be a prevalent translation pattern and only in a small percentage of cases it is rendered with the corresponding Italian word procedere, which is also non-implicative.

Table 4. Raw and percentage frequency of Italian translations of proceed in OPUS

\begin{tabular}{lll}
\hline Frequency & Raw frequency & Percentage frequency \\
\hline fare & 206 & $5.10 \%$ \\
passare & 194 & $4.80 \%$ \\
andare & 160 & $3.96 \%$ \\
continuare & 126 & $3.11 \%$ \\
seguire & 59 & $1.46 \%$ \\
procedere & 42 & $1.39 \%$ \\
other & 3378 & $83.63 \%$ \\
\hline
\end{tabular}

Finally, resume is the least frequent aspectualizer of all, but its semantics corresponds to a large extent to that of riprendere in Italian (Table 5), which also presupposes 'restarting after an interruption'.

Table 5. Raw and percentage frequency of Italian translations of resume in OPUS

\begin{tabular}{lll}
\hline Frequency & Raw frequency & Percentage frequency \\
\hline riprendere & 1,455 & $65.42 \%$ \\
continuare & 47 & $2.11 \%$ \\
other & 769 & $34.57 \%$ \\
\hline
\end{tabular}

The Tables above show that all four English aspectualizers may be translated with continuare, albeit with different frequencies. This suggests that continue and continuare entail the most basic and prototypical meaning of the predicates under investigation here. The two verbs are conceptually less complex, because they express a generic continuative meaning, which can be adapted to meet various requirements. The other verbs are marked for specific semantic features that instead impose constraints at various linguistic levels.

\section{Cognitive Representations}

The two main cognitive operations that will be addressed in this section are metonymy and metaphor. The study of the impact of language-external forces on structural representation started developing in the mid-1990s. Most linguists primarily investigated metonymic structure (e.g., Pustejovsky, 1995; Pustejovsky \& Bouillon, 1995; Verspoor, 1997), disregarding the fact that metaphoric mappings are also responsible for the subcategorization frame of verbs. Aspectual verbs, too, have been mostly analyzed with respect to metonymy (Egg, 2003; Ziegeler, 2007; Sweep, 2010, 2011; Falkum, 2011) and only recently has research begun to recognize that metaphor also determines their various forms and meanings (Franceschi, 2014, 2015, 2017).

Metonymy and metaphor are exploited to varying degrees within and across languages. They can be productive in one language and restricted or even blocked in another; they may motivate certain patterns but not others in the same language; they may work in isolation or in combination, often producing conceptual complexes (Ruiz de Mendoza, 2017). Before considering the differences between English and Italian with respect to the mapping operations underlying continuative verb constructions, let us briefly establish definitions for metonymy and metaphor.

\subsection{Metonymy}

Metonymy is a conceptual phenomenon consisting in using "one entity to refer to another that is related to it" (Lakoff \& Johnson, 1980, p. 35). The connection between the two entities takes place within the same domain, thus creating a relation of contiguity, i.e., 'closeness' of association. Therefore, metonymy is often described as a 'stand for' relation (Kövecses \& Radden, 1998), because one entity 'provides access to' another one with which it has close links, e.g., The planes are on strike (the word planes is not used to refer to the actual aircrafts, but to the pilots 
and staff working on them).

Metonymy is ubiquitous in language and has repercussions both at the lexical and grammatical level (Note 40). The word 'metonymic' has been used to refer to indeterminacy in language (Langacker, 2009), as in the example provided above, in which the choice of the word planes only generically refers to what is actually meant, as well as in those cases where grammar only partially characterizes meaning, e.g. He started towards the door, I began the book, etc. These two constructions are possible thanks to a metonymic operation, whereby started is conceptualized as 'started walking' or 'started running' and the book as 'reading the book' or 'writing the book', respectively. The exact active zones (Langacker, 1984), i.e., the underspecified but relevant meaning components, can only be derived contextually and/or through world knowledge.

\subsection{Metaphor}

Unlike metonymy, which is based on contiguity, metaphor involves a mapping across domains (Note 41) and is thus based on a relation of similarity (Peirsman \& Geeraerts, 2006). So, for example, we might compare a couple arguing to two enemy countries fighting each other, hence the conceptual metaphor LOVE IS WAR, which gives rise to a number of linguistic instantiations, such as One of the partners began the conflict by giving little sarcastic jabs or The couple has made peace, and so on. In this metaphor, FIGHT, CONFLICT, PEACE, LOVE and WAR are all domains and there is a mapping from the domain of ARGUING or FIGHTING to the domain of CONFLICT and WAR.

As in the case of metonymy, metaphors may also generate grammatical forms. This phenomenon can be observed when a concept that is typically expressed with one grammatical form is expressed by means of another. Consider, for example, the use of give in Tom gave John the book and Tom gave John a kiss. In Tom gave John a kiss the prototypical 'transfer' meaning of the verb, which finds expression through the ditransitive construction, is exploited to create a link between the idea of a transfer of objects and that involving the manifestation of affection. This is possible if we conceptualize the object of giving not as something that the giver physically possesses. In other words, the agent who performs the action of kissing does not 'have the kissing' before giving it.

Despite the theoretical distinction between metonymy and metaphor, the boundary between them is often blurred. Although there is no relation between 'giving a book' and 'giving a kiss', for example, we might argue that they both imply the concept of exchanging something. Therefore, in practice, metonymy and metaphor may be difficult to separate and should best be viewed as sitting along a continuum ranging from literal to metaphoric language use, with metonymy occupying the in-between positions (Dirven, 2003).

\subsection{Mapping Operations Underlying English and Italian Aspectual Verb Constructions}

As anticipated above, the cognitive operations underlying the same construction types in different languages may vary. Although there is some overlap between English and Italian with respect to aspectual verb constructions, the two languages also present differences in the way they construe continuative events. These differences are not arbitrary, but rather motivated by the internal semantics of the continuative aspectualizers themselves.

\subsubsection{Keep and Mantenere}

We have seen that these two verbs share a number of syntactic and semantic properties. However, they are etymologically unrelated. They both originally refer to 'seizing' and 'holding', but mantenere is more specific than keep, because it indicates 'holding with your hand' (Lat. manu $>$ hand + tenere $>$ hold). The fact that keep is lexically more generic, instead, may be exploited to produce an underspecified pattern:

(26) Not only does the gyroscope maintain an even balance for itself, but it keeps upright whatever it is placed on. (Note 42)

This syntactic realization is licensed by a target-in-source generic for specific metonymy (cf. Ruiz de Mendoza 2000), because the continuative aspectualizer only partially codes the meaning it expresses, i.e., keep refers to 'keep standing' here. This cognitive operation is not required for the interpretation of a similar construction in Italian, in that mantenere also entails the sense of 'physically remaining':

(27) Pertanto un siffatto giroscopio si mantiene verticale [...] e ruota intorno all'asse [...]. (Note 43)

[Therefore, such a gyroscope keeps vertical and rotates about an axis...]

Due to its generic semantic nature, keep almost seems to work as a copular verb in this context, while mantenere has a richer lexical structure.

There are other syntactic patterns involving keep that need to be interpreted figuratively. The following example presents a similar scenario to that discussed above:

(28) Like a train unable to leave its track she kept with the stream of cars onto the concrete road [...]. (Note 44) 
What is implied is again something more specific (i.e., 'keep driving/moving'), which does not have lexicalized form here. Interestingly, keep may be translated with the verb rimanere in Italian. Although this verb is not a continuative aspectualizer per se, its semantics overlaps with that of mantenere and is therefore allowed in this context:

(29) Come un treno incapace di lasciare le rotaie rimase nel flusso di macchine sulla strada di cemento [...]. (Note 45)

\subsubsection{Continue and Continuare}

These two verbs are the most similar with respect to the cognitive operations underlying their uses. They typically participate in metonymic constructions that are, to a great extent, conventionalized. The action they refer to may remain unexpressed, but still be pragmatically retrievable from the context. In the following sentences, for example, both continue and continuare stand for 'continue working':

(30) a. Huxley continued as mayor of the newly united town. (Note 46)

b. Continuo come sindaco di Bergamo. (Note 47)

The only significant difference emerges when they express an existential meaning. While continue may remain underspecified with respect to this meaning component, because it is part of its semantic makeup, continuare must necessarily be followed by an existence predicate:

(31) a. Many barriers continue to the paths of most women, even on the most basic issue of equal pay for equal work. (Note 48)

b. [...] le condizioni personali e nazionali continuano a presentare molti ostacoli per coloro che le attraversano. (Note 49)

The Italian sentence would be ungrammatical without the $a+$ infinitive construction. On the other hand, the presence of a complement clause is not obligatory in English. This suggests that continuare is semantically more neutral than continue. Therefore, the former imposes a higher level of specification, while the latter may remain lexically vague.

\subsubsection{Proceed and Procedere}

Unlike the other verb pairs, proceed and procedere also enter metaphoric constructions. This happens because their prototypical meaning, which is linked in both cases to the idea of physical movement, is "manipulated" to express more complex concepts than that of simply 'going forwards'. What we see in the examples below, for instance, is a cross-domain mapping whereby proceed and procedere are understood as 'derive':

(32) a. Her awkwardness [...] proceeds from shyness [...]. (Note 50)

b. La sua titubanza procede da timidezza. (Note 51)

[His/her hesitance proceeds from shyness]

Even the temporal interpretation of the two verbs is secondary to their primary spatial sense and is therefore metaphorical:

(33) a. [...] the game proceeds easily. (Note 52)

b. [...] la conversazione procede agevolmente. (Note 53)

It can be observed in (33) that both proceed and procedere mean 'continue'. However, a double cognitive operation is required for the interpretation of the English sentence. Proceed is first understood metaphorically as 'continue', but then it also undergoes a metonymic shift that makes it possible to read it as 'continue to be played'. This is because the subject of the sentence is not a deverbal noun, as in the case of the Italian sentence where la conversazione (the conversation) implicitly encodes the action.

\subsubsection{Resume and Riprendere}

The main difference between this pair of verbs concerns the type of metonymic constructions they can participate in. We have an opposite scenario compared to what happens with continue and continuare, i.e., it is the Italian aspectualizer riprendere that can remain underspecified and not its English counterpart, which instead requires the explicitation of a certain action:

(34) a. Il geranio dopo che l'ho annaffiato pare che riprenda. (Note 54)

b. The roots remain viable and the plant resumes growing the following spring. (Note 55)

While, in this case, the sense of 'growing' is embedded in the meaning of riprendere, it must be lexically expressed 
in English, because resume is more generic. Similarly, there are other situations in which riprendere only partially codes the meaning it expresses, as can be observed below with reference to the concept of 'knitting':

\section{(35) a. Riprendere una maglia (Note 56)}

b. Jennifer settled into a chair beside Kelly and resumed knitting the blue and white patterned sweater. (Note 57)

The removal of the complement verb in English would come across as odd, while this is possible and somewhat natural in Italian.

Finally, there are a number of idiomatic expressions in Italian in which riprendere stands alone, with specific meanings. The reflexive use of the verb, for instance, is generated by a metaphoric interpretation whereby riprendersi is 'recovering' or 'regaining strength', both physically, emotionally and financially:

(36) a. Mi sono ripreso dopo quasi un mese trascorso in terapia intensiva. (Note 58)

[I have recovered after spending about a month in the ICU]

b. Mi sono ripreso dalla sorpresa e mi sono presentato. (Note 59)

[I have recovered from the surprise and introduced myself]

\section{c. Finanziariamente, mi sono ripreso bene. (Note 60)}

[Financially, I have recovered well]

This possibility is ruled out in English, because resume generally requires some form of complementation or the presence of a deverbal subject, which at least implicitly refers to a certain action. There is just one exception, i.e., when the meaning of resume is conventionally assigned via metonymy to refer to the act of talking, as also in the case of other aspectualizers:

(37) a. And suddenly he resumed: "I'm not a gentleman, sir; but I will tell the truth." (Note 61)

b. Wolff answered, "The Talmud is a lie;" and then he continued, "The Talmud is a lie!" [...]. (Note 62)

\section{Conclusions}

This paper has attempted to highlight the areas of overlap and contrast between English and Italian with respect to the use of continuative aspectualizers. It is an initial investigation based on the analysis of a small dataset, which, however, makes it possible to show the main similarities and differences in the form-meaning representations of these verbs in the two languages.

Syntactically, Italian appears as more static than English, because the continuative aspectualizers examined here, with the only exception of (man)tenere, which does not combine with verbal complement clauses at all, may only be followed by the ' $a+$ infinitive' construction, while both the to-infinitive and the -ing forms are typically associated to continuative aspectualizers in English; keep only allows for the use of the gerund form, because its inherent semantics is highly progressive, thus blocking its combination with the to-infinitive, which has a prospective future sense, instead.

Italian seems to allow richer lexical representations, sometimes consisting of idiosyncratic expressions, such as the far(e) sì che construction, which do not have literal counterparts in English. MultiWordNet has allowed us to observe the existence of dynamic cross-linguistic semantic correspondences, each of which has a number of related senses in one language that do not necessarily match with those associated with the corresponding verb in the other language. While continue and continuare, proceed and procedere, resume and riprendere are etymologically related, keep and (man)tenere are not. Therefore, finding a connection between them is more problematic.

Finally, it has been observed that the semantics of continuative aspectualizers can be variously "manipulated", both in English and Italian, to produce non-literal interpretations resulting from metonymic and metaphoric mapping operations. Metonymic constructions are extremely widespread in the two languages, while metaphoric extensions appear to concern only proceed and procedere, which have significantly distanced themselves from their original spatial sense.

\section{References}

Bailey, D. (1993). The Problem of the Alternation of to V/V-ing after 'Aspectual' Verbs. In J. Chuquet \& D. Roulland (Eds.), Subordination, Subordinations (pp. 185-197). Rennes: Presses Universitaires de Rennes II. 
Bertuccelli Papi, M. (2003). Cognitive complexity and the lexicon. In M. Merlini Barbaresi (Ed.), Complexity in Language and Text (pp. 67-115). Pisa: Pisa University Press.

Bertuccelli Papi, M. (2016). Prima di tradurre. Note sui vincoli strutturali, concettuali e culturali nella traduzione dall'inglese all'italiano. Pisa: Pisa University Press.

Bassnett, S., \& Bush, P. (2006). (eds.). The Translator as Writer. London/New York: Bloomsbury/Continuum.

Biber, D. et al. (1999). Longman Grammar of Spoken and Written English. Harlow: Pearson Education Limited.

Brinton, L. (1988). The Development of English Aspectual Systems. Cambridge: Cambridge University Press.

Dirven, R. (2003). Metonymy and Metaphor: Different Mental strategies of conceptualization. In R. Dirven \& R. Pöring (Eds.), Metaphor and Metonymy in Comparison and Contrast (pp. 75-112). Berlin/New York: Mouton de Gruyter. https://doi.org/10.1515/9783110219197.1.75

Duffley, P. (1999). The use of the infinitive and the -ing after verbs denoting the beginning, middle and end of an event. Folia Linguistica, 33, 295-331. https://doi.org/10.1515/flin.1999.33.3-4.295

Duffley, P. (2006). The English Gerund-Participle. A Comparison with the Infinitive. New York: Peter Lang Publishing.

Egg, M. (2003). Beginning Novels and Finishing Hamburgers. Remarks on the Semantics of TO BEGIN. Journal of Semantics, 20, 163-191. https://doi.org/10.1093/jos/20.2.163

Falkum, I. L. (2011). The semantics and pragmatics of polysemy: A relevance-theoretic account. $\mathrm{PhD}$ thesis University College London. London: UCL.

Franceschi, D. (2014). Licensing and blocking factors in the use of BEGIN verbs: a lexical-constructional and pragmatic analysis. Review of Cognitive Linguistics, 12(2), 302-341. https://doi.org/10.1075/rcl.12.2.03fra

Franceschi, D. (2015). Ingressive and Egressive Verbs in English: A Cognitive-Pragmatic Approach to Meaning. Newcastle-Upon-Tyne: Cambridge Scholars Publishing.

Franceschi, D. (2017), Metonymy and Metaphor in the Construction of Meaning of English Continuative Verbs. In A. Baicchi \& A. Bagascheva (Eds.), Textus - English Studies in Italy (vol. 30, pp. 63-77). Roma: Carocci Editore.

Freed, A. (1979). The Semantics of English Aspectual Complementation. Dordrecht: D. Reidel. https://doi.org/10.1007/978-94-009-9475-1

Fukuda, S. (2007), On the control/raising ambiguity with aspectual verbs: a structural account. In B. Stiebels (Ed.), Papers in Linguistics (vol. 47, Studies in Complement Control, pp. 159-195). Retrieved April 5, 2020, from http://citeseerx.ist.psu.edu/viewdoc/download?doi=10.1.1.117.4166\&rep=rep1\&type=pdf

García, E., Florimon van Putte, C. M., \& Yishai, T. (1987). Cross-linguistic equivalence, translatability, and contrastive analysis. Folia Linguistica, 21(2/4), 373-405.

Langacker, R. (1984). Proceedings of the Tenth Annual Meeting of the Berkeley Linguistics Society (pp. 172-188). https://doi.org/10.3765/bls.v10i0.3175

Langacker, R. (1987). Foundations of cognitive grammar. Theoretical prerequisites. Stanford, CA: Stanford University Press.

Langacker, R. (2009), Metonymic grammar. In K.-U. Panther, L. Thornburg \& A. Barcelona (Eds.), Metonymy and Metaphor in Grammar (Human Cognitive Processing 25, pp. 45-71). Amsterdam/Philadelphia: John Benjamins. https://doi.org/10.1075/hcp.25.04lan

Littlemore, J. (2015). Metonymy. Cambridge: Cambridge University Press. https://doi.org/10.1017/CBO9781107338814

Mair, C. (2009). Complement Clauses in English. Cambridge: Cambridge University Press.

Michaelis, L. (2003). Word meaning, sentence meaning, and syntactic meaning. In H. Cuyckens, R. Dirven \& J. Taylor (Eds.), Cognitive approaches to lexical semantics (pp. 93-122). Berlin: Mouton de Gruyter. https://doi.org/10.1515/9783110219074.163

Peirce, C. S. (1965). Collected Papers. Cambridge: Harvard University Press.

Peirsman, Y., \& Geraeerts, D. (2006). Metonymy as a Prototypical Category. Cognitive Linguistics, 17(3), 269316. https://doi.org/10.1515/COG.2006.007 
Pustejovsky, J. (1995). The generative lexicon. Cambridge, MA: MIT Press.

Pustejovsky, J., \& Bouillon, P. (1995). Aspectual coercion and logical polysemy. Journal of Semantics, 12(2), 133-162. https://doi.org/10.1093/jos/12.2.133

Raw, L. (2012). (ed.). Translation, Adaptation and Transformation. London/New York: Bloomsbury/Continuum.

Ruiz de Mendoza Ibáñez, F. J. (2000). The role of mappings and domains in understanding metonymy. In A. Barcelona (Ed.), Metaphor and Metonymy at the crossroads (pp. 109-132). Berlin/New York: Mouton de Gruyter.

Ruiz de Mendoza Ibáñez, F. J. (2017). Conceptual complexes in cognitive modeling. Spanish Journal of Applied Linguistics, 30(1), 299-324. https://doi.org/10.1075/resla.30.1.12rui

Sweep, J. (2010). A frame-semantic approach to logical metonymy. Constructions and Frames, 2(1), 1-32. https://doi.org/10.1075/cf.2.1.01swe

Sweep, J. (2011). Metonymical transfers: The complex relation of metonymy and grammar. ACLC, Universiteit van Amsterdam.

Tobin, Y. (1993). Aspect in the English Verb: Process and Result in Language. London: Longman.

Tognini Bonelli, E. (2002). Functionally complete units of meaning across English and Italian. Towards a corpus-driven approach. In B. Altenberg \& S. Granger (Eds.), Lexis in Contrast. Corpus-based approaches (pp. 73-96). Amsterdam/Philadelphia: John Benjamins. https://doi.org/10.1075/scl.7.07tog

Verspoor, C. M. (1997). Conventionality-governed logical metonymy. In H. Bunt, L. Kievit, R. Muskens \& H. Verlinden (Eds.), Proceedings of the Second International Workshop on Computational Semantics (pp. 300-312). Tilburg.

Ziegeler, D. (2007). Arguing the case against coercion. In G. M. Radden, K.-M. Köpcke, T. Berg \& P. Siemund (Eds.), Aspects of Meaning Construction (pp. 99-123). Amsterdam/Philadelphia: John Benjamins. https://doi.org/10.1075/z.136.08zie

\section{Notes}

Note 1. http://opus.nlpl.eu.

Note 2. https://www.sketchengine.eu.

Note 3. Google Books search: Marshall, B. M. (2011), The Transatlantic Gothic Novel and the Law, 1790-1860, p. 27.

Note 4. Google Books search: McCammon, R. (2009), Swan Song, p. 775.

Note 5. Google Books search: McBride D. (2005), Why I Hate Abercrombie \& Fitch: Essays on Race and Sexuality, p. 51.

Note 6. Both proceed and procedere tend to be complemented by a prepositional phrase, e.g., [...] the 16 national central banks of the euro area will proceed with the preparatory work for the establishment of loan-level information requirements. > [...] le banche centrali nazionali dei 16 paesi dell'area dell'euro procederanno con $i$ preparativi per la definizione dei requisiti.

Note 7. Google Books search: Eppler, S. \& Woodcock, M. (2001), Sunshine and Shadows: The Sunny Marie Eppler Story, p. 38.

Note 8. Google Books search: Palek, T. (2014), I Always Hear Music, p. 189.

Note 9. Google Books search: Chase, E. (2011), The \$5 Dinner Mom Breakfast and Lunch Cookbook, p. 26.

Note 10. Google Books search: Pandiani, M. (2016), Il grande inganno del cibo.

Note 11. Google Books search: Balossi, A., Clark, C., Coco, R.S. (2011). Noblest. Volume II. An Anthology of Prose and Poetry, p. 285.

Note 12. Google Books search: Tosi, G. (2006), Vita coi nipoti. Il nonno racconta e riflette, p. 116.

Note 13. Google Books search: Jarvis, R.C. (1954), Customs Letter-books of the Port of Liverpool, 1711-1813, p. 50 .

Note 14. Google Books search: Van Dover, C.L. (1997), Tremila metri sotto i mari. I viaggi nel mondo degli abissi, 
p. 75.

Note 15. Google Books search: Badolati, A. (2014), Ouitalos.

Note 16. Google Books search: Fogazzaro, A., Morra, O. (1960), Fogazzaro nel suo piccolo mondo dai carteggi familiari, p. 359.

Note 17. This is a rather crystallized use in Italian, which also appears in dictionaries, e.g., http://www.treccani.it/vocabolario/mantenere

Note 18. Google Books search: Bergson, H., Larrabee, H. A., Selections from Bergson, p. 95.

Note 19. Google Books search: Rescher, N. (2003), Nature and Understanding, p. 51.

Note 20. Google Books search: Carlson, M. (2012), River's End, p. 7.

Note 21. http://www.treccani.it

Note 22. Google Books search: Draughon, D. (2007), Financial Armageddon. The Corruption of our Currency, p. 224.

Note 23. http://theyardrake.blogspot.com/2015/02/

Note 24. My translation.

Note 25. My translation.

Note 26. Google Books search: Silva, J.M. (2013), Coming Up Short, p. 120.

Note 27. Google Books search: Dicker, K. (2010), Properties of Matter.

Note 28. Google Books search: Lepore, G. (2016), Angelo che sei il mio custode.

Note 29. http://ilariaandlife.blogspot.com/2014/09/unif-crayola-oversized-sweater.html

Note 30. Google Books search: Walker, S.R. (2014), two west, p. 73.

Note 31. Google Books search: Ciccola, C. et al. (2014), Il trattamento dei disturbi alimentari in contesti istituzionali, p. 131.

Note 32. Google Books search: Cabon, M. (2013), Telegraph Avenue.

Note 33. The version including the Italian component (http://multiwordnet.fbk.eu/english/home.php) is aligned with Princeton WordNet 1.6.

Note 34. In WordNet the lexical variants of the same concept are called synsets. They consist of sets of words related by synonymy that can be interchanged.

Note 35. My translation.

Note 36. Diagrammaticity is a concept drawn from Peirce's semiotics (1965), which refers to the relation of analogy, or lack thereof, between form (signans) and meaning (signatum). In particular, it concerns the distance separating "the lexico-semantic from the cognitive schemata" (Bertuccelli Papi 2003: 92).

Note 37. The different senses of keep, which prototypically referred to 'seizing' or 'holding', exploded in Middle English: "to guard, defend" (12c.); "restrain (someone) from doing something " (early 13c.); "take care of, look after; protect or preserve (someone or something) from harm, damage, etc." (mid-13c.); "preserve, maintain, carry on" a shop, store, etc. (mid-14c.); "prevent from entering or leaving, force to reman or stay" (late 14c.); "preserve (something) without loss or change," also "not divulge" a secret, private information, etc., also "to last without spoiling" (late 14 c.); "continue on" (a course, road, etc.), "adhere to" a course of action (late 14 c.); "stay or remain" (early 15 c.); "to continue" (doing something) (mid-15c.). It is used to translate both Latin conservare "preserve, keep safe" and tenere "to keep, retain". (https://www.etymonline.com/search?q=keep).

Note 38. The meaning of preservare is that of 'saving' or 'defending', which presupposes the idea of external harm.

Note 39. Permanere expresses the idea that something continues for a long period of time, e.g., La situazione permane difficile [the situation continues to be/remains difficult].

Note 40. See Littlemore (2015) for a comprehensive and updated treatment of metonymy in language.

Note 41. The concept of 'domain' was introduced by Langacker (1987) to indicate the knowledge that we have about a particular entity.

Note 42. Google Books search: Talbot, L.T. (1934), Objects That Talk and Teach. 
Note 43. Google Books search: Ciancitto, A. (2003), La fisica reale Teoria dei fotoni e degli elettroni, p. 219.

Note 44. Google Books search: Burns, P. (2012), With a Little Help from My Friends, chapter 11.

Note 45. My translation.

Note 46. Google Books search: Foster, L.F., Griffith, A.G. (2001), Bordering on Greatness, p. 46.

Note 47. http://www.milanoallnews.it/gori-lascia-il-consiglio-regionale-continuo-come-sindaco-di-bergamo/

Note 48. Google Books search: Engdahl, S. (2012), The Women's Liberation Movement, p. 135.

Note 49. Google Books search: De Bonis, M.G. et al. (2009), Il cinema israeliano contemporaneo, p. 118.

Note 50. Google Books search: Mullan, J. (2012), What Matters in Jane Austen?: Tenty Crucial Puzzles Solved, p. 136.

Note 51. http://www.treccani.it

Note 52. Google Books search: Zelan, K. (2007), Between Their World and Ours.

Note 53. Google Books search: Iavarone, M. (2002), Libera le tue ali, p. 78.

Note 54. http://www.treccani.it

Note 55. Google Books search: Iannotti, M. (2012), The Beginner's Guide to Growing Heirloom Vegetables.

Note 56. http://www.treccani.it

Note 57. Google Books search: Sefton, M. (2007), A Killer Stich.

Note 58. Google Books search: Hamer, M. (2007), Come ci si sente ad essere attaccati da uno squalo.

Note 59. Google Books search: Ricci, P. (2019), Il Gesù clonato e l'Anticristo vegetariano.

Note 60. Google Books search: Maiorano, P. (2014), Avrò fatto la scelta giusta?

Note 61. Google Books search: MacDonald, G. (2017), The Parish Trilogy.

Note 62. Google Books search: Wolff, J. (2012), Travels and Adventures of Rev. Joseph Wolff, p. 174.

\section{Copyrights}

Copyright for this article is retained by the author, with first publication rights granted to the journal.

This is an open-access article distributed under the terms and conditions of the Creative Commons Attribution license (http://creativecommons.org/licenses/by/4.0/). 